\title{
Epidemiological profile and treatment of substance losses by trauma to the lower limbs
}

\section{Perfil epidemiológico e tratamento de perdas de substância por trauma em membros inferiores}

\author{
Ricardo Barros Martins Rezende ${ }^{1}$; Jefferson lessa Soares de Macedo, tCbC-DF1; Simone Corrêa Rosa ${ }^{1}$; Fernando Soares Galli
}

\begin{abstract}
A B S T R A C T
Objectives: to evaluate the epidemiological profile, the surgical treatment and the postoperative results of patients with complex traumatic injuries to the lower limbs. Methods: we conducted a retrospective study of patients with traumatic complex injuries treated by the Plastic Surgery Service of a regional hospital in Brasilia. We analyzed clinical-epidemiological data, type of surgical procedure and functional recovery of the limb after six months of treatment. Results: 119 patients were treated, with a mean age of 29 years, predominantly men (76.4\%). Motorcycle accident was responsible for most of the injuries, in 37.8\% of cases. The most frequent surgical treatment was skin grafting (62.1\%), followed by the fasciocutaneous flap (21.9\%), muscular flap (12.6\%) and microsurgical flap (3.4\%). Six months after completion of the surgical treatment, $35.3 \%$ of the patients needed crutches to move, characterizing a delay in limb functional recovery that, however, was significantly related to the presence of fractures, external fixation or bone exposure in the preoperative period. Conclusion: the profile of the patient with complex traumatic lower limb injury was a male, motorcycle accident victim, and grafting was the most used treatment. Orthopedic trauma with bone fracture, bone exposure and the presence of external fixator were significantly associated with a higher risk of limb functional impairment, requiring locomotion crutches after six months of treatment.
\end{abstract}

Keywords: Lower Extremity. Wounds and Injuries. Surgical Flaps. Surgery, Plastic. Health Profile.

\section{INTRODUCTION}

$H^{i}$ gh-energy trauma has increased significantly in the last decades, mainly due to auto and motorcycles accidents. Trauma victims may have lesions of varying severity and location, the lower limbs being an important site of injury. These can vary from simple skin solutions of continuity to great tissue losses and exposure of noble structures ${ }^{1,2}$. Lesions severity and treatment difficulties require professional knowledge and familiarity with repair techniques, making reconstructions of the lower limbs a challenge for the surgeon. The scarcity of adjacent tissues is one of the difficulties in the search for reconstruction ${ }^{1,2}$.

The lower limbs have peculiar anatomical features that make their reconstruction a complex theme. These include the need to support body weight, a greater propensity to develop deep venous thrombosis, problems with venous stasis and chronic edema, frequent occurrence of atherosclerosis and difficult nervous regeneration ${ }^{3,4}$. It is essential to know in detail the anatomical structures, the etiopathology of the lesion and to have a multidisciplinary team throughout the process of reconstruction and rehabilitation. Functional recovery should always be sought, regardless of the proposed treatment, be it reconstruction or amputation $^{3-6}$.

The objective of this study is to evaluate the epidemiological profile, the treatment offered and the postoperative results of victims of trauma to the lower limbs admitted to the Plastic Surgery Service of the North Wing Regional Hospital, Brasília - DF.

\section{METHODS}

This is a retrospective study of patients admitted to the Plastic Surgery Service of a regional public hospital, who had wounds with loss of substance

1 - North Wing Regional Hospital, Plastic Surgery Service, Brasília, DF, Brazil. 
in the lower limbs due to trauma, from January 2011 to December 2015. Patients were admitted after clinical and surgical control of their wounds by other specialties, such as orthopedics and general surgery. Exclusion criteria were: patients with chronic ulcers or loss of substance in the lower limbs whose etiology was vascular, lymphatic or oncologic.

The demographic data studied were gender, age, origin, trauma mechanism and the most affected region of the lower limb. In addition, we also evaluated the characteristics of the wound, such as presence of preoperative fracture, bone exposure and presence of external fixator.

We analyzed the type of reconstructive surgical treatment and counted only the main procedure of each patient for data analysis. For example, in the case of a sural flap, the graft donor area is covered with skin graft. In these cases, we counted only the fasciocutaneous flap, since the graft would be a complementary treatment of the sural flap. In some patients, surgical debridements were isolated or associated with negative pressure therapy (vacuum system). After wound preparation, the patients underwent reconstructive surgical procedures, such as skin grafts, fasciocutaneous flaps, muscle flaps, or microsurgical flaps.

We classified tissue integration as complete when the graft or flap had no ischemia or necrosis, as partial when there was partial loss, and as necrosis when there was complete loss of the treatment applied. Finally, we analyzed the functional recovery of the limb and the need for crutches six months after the surgical treatment, information obtained by the medical record or by direct contact with the patient.

We used the Epiinfo 7.15 software for statistical analysis. The study was approved by the Ethics in Research Committee of the State Department of Health of the Federal District (CAAE number: 47391715.6.0000.5553, opinion number: 1,167,841).

\section{RESULTS}

The sample consisted of 119 patients, with a predominance of the male gender $(76.4 \%$ of cases) and age ranging from two to 70 years (mean 29). The patients' origin was mainly from the Federal District
(65.5\%), followed by the cities around it, mainly from the state of Goiás. The hospitalization time ranged from one to 160 days, with average 21.2 (Table 1).

Table 1. Demographic data of victims of lower limbs trauma with loss of substance admitted to the North Wing Regional Hospital, Brasilia/DF, in the period of 2011 to 2015.

\begin{tabular}{lcc}
\hline Gender & $\mathrm{N}$ & $\%$ \\
\hline Male & 91 & 76.4 \\
Female & 28 & 23.6 \\
Origin & & \\
Federal District & 78 & 65.5 \\
Goiás & 32 & 26.9 \\
\hline Other & 9 & 7.6 \\
Age group & & \\
0-19 & 26 & 21.8 \\
$20-29$ & 40 & 33.6 \\
$30-39$ & 20 & 27.8 \\
\hline$\geq 40$ & 33 & 27.8 \\
Total & 119 & 100 \\
\hline
\end{tabular}

$N=$ number of cases; $\%=$ percentage of total cases.

The most frequent etiology of the injuries was motorcycle accident (37.8\% of cases), followed by trampling (30.3\%) and auto accident (11.8\%). The lower third of the leg was the most affected area, in $50.4 \%$ of patients, followed by the middle third of the leg, in 32\% (Table 2).

Regarding the preparation of traumatic lesions for the reconstructive surgical procedure (graft or flap), $25(21.0 \%)$ patients required isolated debridements, and $15(12.6 \%)$, debridement associated with vacuum therapy.

Tibial fracture was present in $44(37.0 \%)$ patients, external fixator in 32 (26.9\%) and there was bone exposure in 37 (31.1\%). Many individuals required more than one surgical procedure for complete reconstruction of the affected limb. The number of reconstructive procedures per patient ranged from one to seven. The total 
number of reconstructive procedures was 224 and the mean reconstructive procedures per patient were 1.88 .

Table 2. Etiology and localization of victims of trauma to the lower limbs with loss of substance admitted to the North Wing Regional Hospital, Brasilia/DF, in the period of 2011 to 2015.

\begin{tabular}{lcc}
\hline Etiology of Trauma & $\mathrm{N}$ & $\%$ \\
\hline Motorcycle accident & 45 & 37.8 \\
Run-over & 36 & 30.3 \\
Automobile accident & 14 & 11.8 \\
Fall from height & 7 & 5.9 \\
Firearm & 6 & 5.0 \\
Other ${ }^{*}$ & 11 & 9.2 \\
\hline
\end{tabular}

Location of lesions

Lower $1 / 3$

60

50.4

Middle 1/3

38

32.0

Upper $1 / 3$

21

17.6

Total

119

100

* Working machine accident, stab wound, injury during run.

$N=$ number of cases; $\%=$ percentage of total cases.
The most frequent surgical procedure was skin grafting (62.1\% of cases) (Table 3 ). The fasciocutaneous flap was the second most frequent procedure and was done in $21.9 \%$ of cases, the reverse sural flap and the neighborhood flaps standing out. Cross-legged flaps were required in $3.4 \%$ of hospitalized patients. Muscle flaps were performed in $12.6 \%$ of the patients, with prominence of the medial head gastrocnemius muscle flap. The microsurgical flap was performed in four patients, representing $3.4 \%$ of the sample (Figures 1 to 3 ).

Patients submitted to cutaneous grafts had a complete integration rate of $86.4 \%, 10.8 \%$ of partial integration, and $2.7 \%$ evolved with necrosis and total graft loss. Fasciocutaneous flaps had a rate of $88.4 \%$ complete integration and $11.5 \%$ partial integration, with no case of total necrosis. Muscle flaps had a $73.3 \%$ complete integration rate and $26.6 \%$ partial integration, also without total necrosis cases. The microsurgical flap was performed in four patients, presenting total loss in one case. The others had complete integration.

Table 3. Relationship of location of the lesions in the leg with the surgical treatment of victims of lower limbs trauma with loss of substance admitted to the North Wing Regional Hospital, Brasilia/DF, in the period of 2011 to 2015.

\begin{tabular}{|c|c|c|c|c|}
\hline Location & Lower 1/3 & Middle 1/3 & Upper 1/3 & Total \\
\hline Type of treatment & $N / \%$ & $\mathrm{~N} / \%$ & $\mathrm{~N} / \%$ & $\mathrm{~N} / \%$ \\
\hline Graft ${ }^{1}$ & $45 / 37.8$ & $17 / 14.3$ & $12 / 10.1$ & $74 / 62.1$ \\
\hline \multicolumn{5}{|l|}{ Fasciocutaneous Flap } \\
\hline Sural ${ }^{2}$ & $8 / 6.7$ & $4 / 3.4$ & 0 & $12 / 10.1$ \\
\hline Neighborhood ${ }^{3}$ & $2 / 1.7$ & $5 / 4.2$ & $3 / 2.5$ & $10 / 8.4$ \\
\hline Cross-leg ${ }^{4}$ & $2 / 1.7$ & $2 / 1.7$ & 0 & $4 / 3.4$ \\
\hline \multicolumn{5}{|l|}{ Muscle flap } \\
\hline Gastrocnemius ${ }^{5}$ & 0 & $6 / 5.1$ & $6 / 5.1$ & $12 / 10.1$ \\
\hline Soleus ${ }^{6}$ & 0 & $3 / 2.5$ & 0 & $3 / 2.5$ \\
\hline Microsurgical ${ }^{7}$ & $3 / 2.5$ & $1 / 0.8$ & 0 & $4 / 3.4$ \\
\hline Total & $60 / 50.4$ & $38 / 32.0$ & $21 / 17.6$ & $119 / 100$ \\
\hline
\end{tabular}



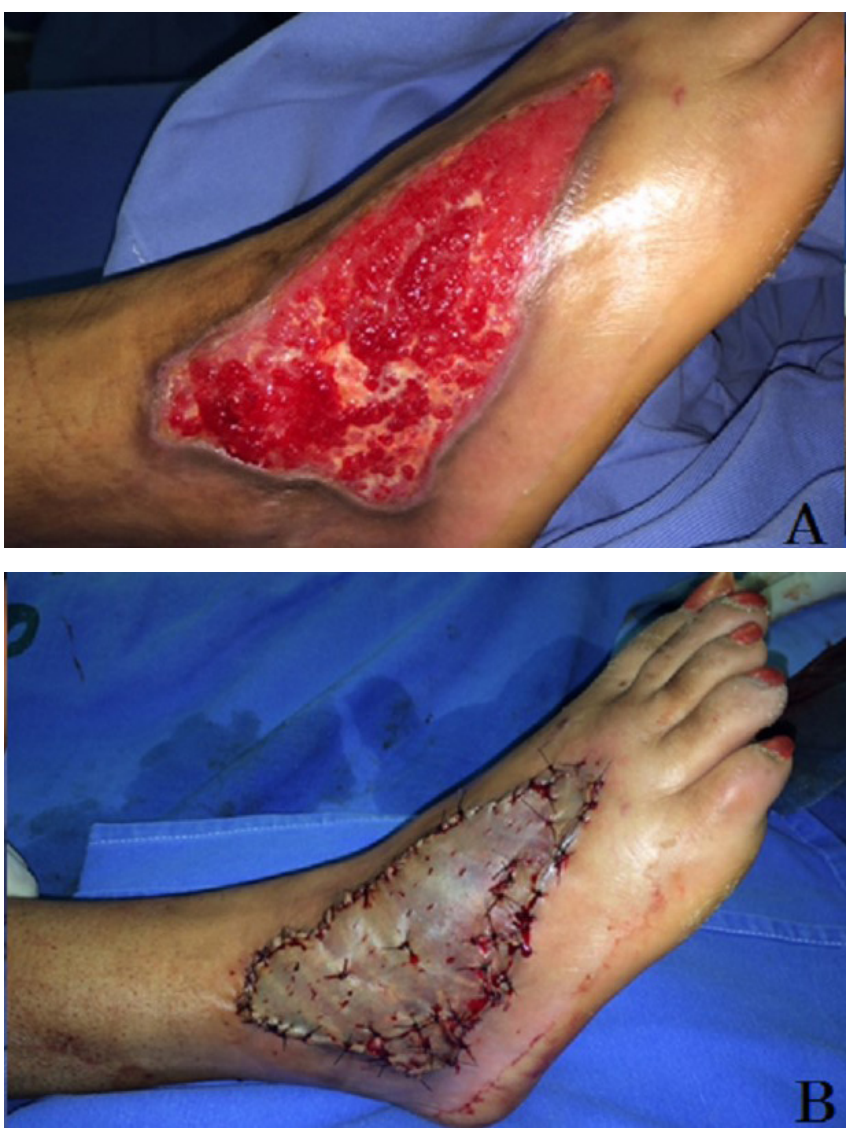

Figure 1. Loss of substance on the back of the foot: A. Preoperative; $B$. Partial skin graft.

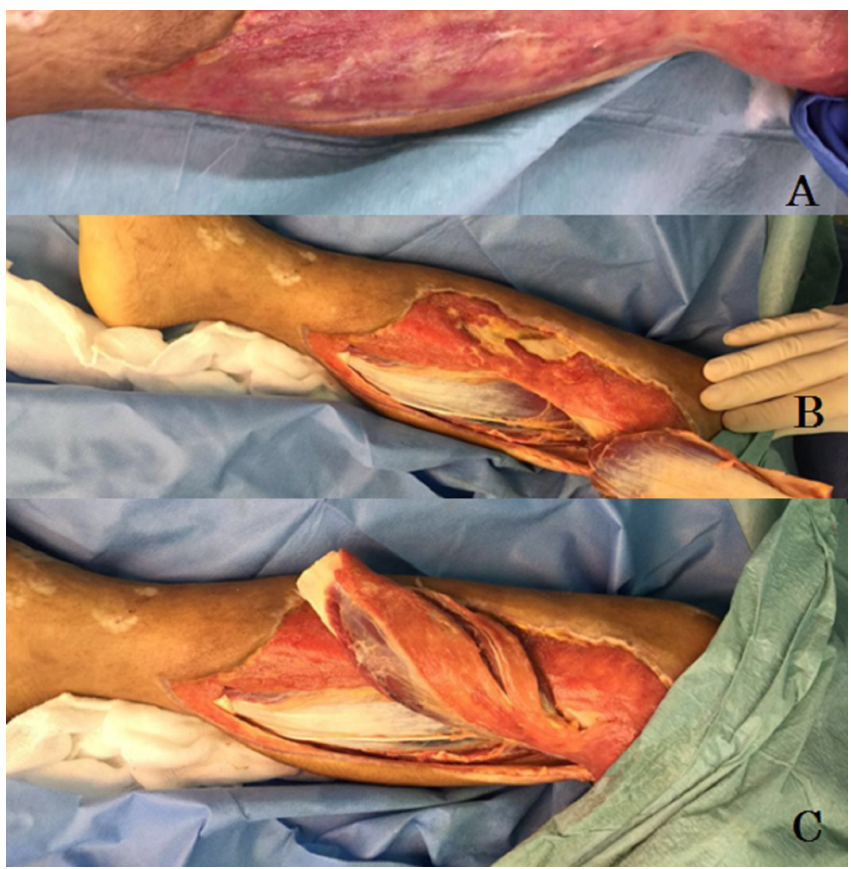

Figure 3. Medial head gastrocnemius muscle flap: A. Tissue loss; $B$. Dissection; C. Mobilization.

Six months after surgical treatment, we evaluated the use of crutches to ambulate in 42 (35.3\%)

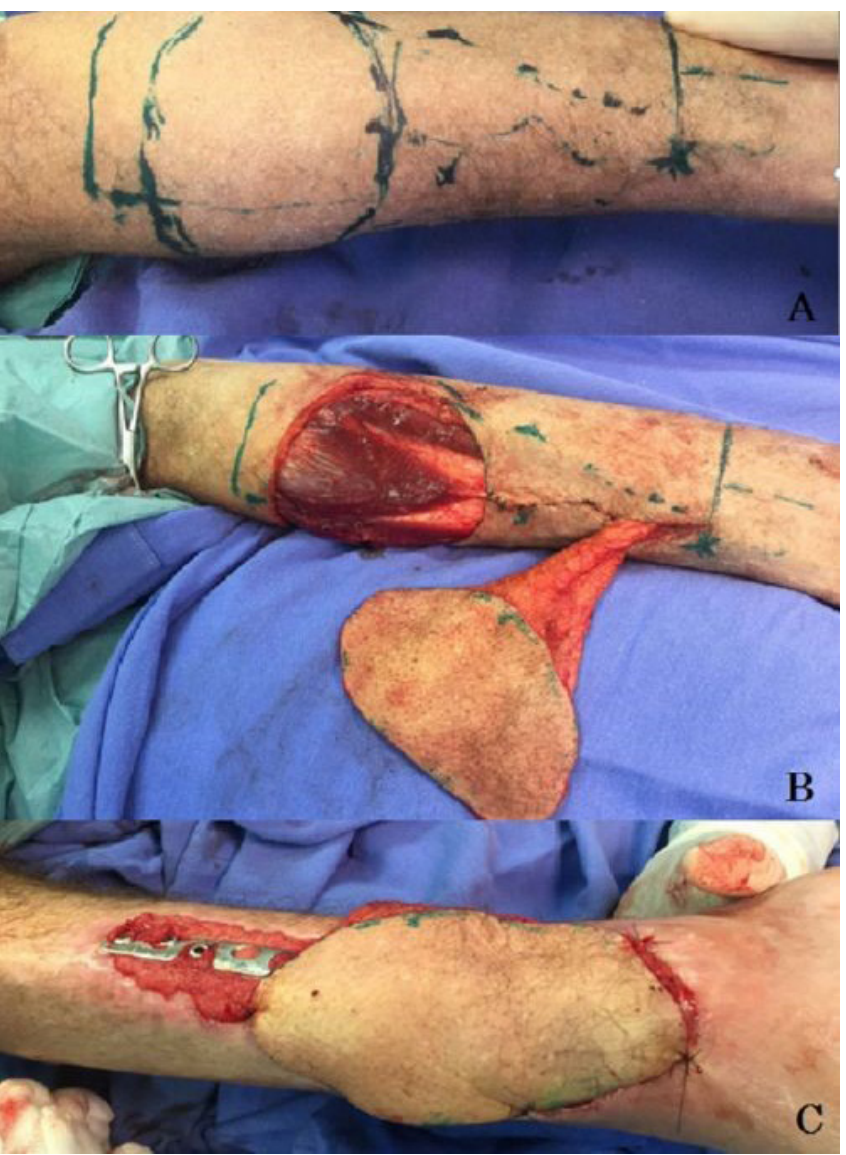

Figure 2. Reverse sural fasciocutaneous flap: A. Marking; B. Muscle preservation; C. Postoperative.

patients. The factors significantly associated with the need to use crutches to walk after six months of surgical treatment for closure of lower limb substance losses were the presence of preoperative tibial fracture $(73.8 \%$ $x 16.9 \%, p<0.01$, OR: 13.8), the use of external fixator $(57.1 \% \times 10.4 \%, p<0.01$, OR: 11.5$)$ and presence of preoperative bone exposure $(52.4 \% \times 19.5 \%, p<0.01$, OR: 4.5) (Table 4).

\section{DISCUSSION}

After the 1970s, repair of loss of lower limb substance evolved with new surgical techniques, with the advent of vacuum therapy and the inclusion of multidisciplinary teams for treatment. Thus, the extremities are now more likely to be recovered ${ }^{3}$. In cases where the extremity cannot be recovered, the amputation stump can be covered with soft tissues to support the prosthesis, allowing functional gait and maximum functional capacity ${ }^{4}$. Therefore, besides the need to cover the wound, there is also a need to allow mobility of the 
Table 4. Factors associated with the use of crutches after surgical treatment of victims of lower limbs trauma with loss of substance admitted to the North Wing Regional Hospital, Brasilia/DF, in the period of 2011 to 2015.

Use of crutches**

\begin{tabular}{lccccc}
\hline Associated factors* & $\begin{array}{c}\text { Yes } \\
\mathrm{N}=42\end{array}$ & $\begin{array}{c}\text { No } \\
\mathrm{N}=77\end{array}$ & Or & $95 \% \mathrm{Cl}$ & $p$ \\
\hline Fracture of tibia & $31(73.8 \%)$ & $13(16.9 \%)$ & 13.8 & $5.5-34.4$ & $<0.01$ \\
Use of external fixator & $24(57.1 \%)$ & $8(10.4 \%)$ & 11.5 & $4.4-29.8$ & $<0.01$ \\
Bone exposure & $22(52.4 \%)$ & $15(19.5 \%)$ & 4.5 & $1.9-10.4$ & $<0.01$ \\
\hline
\end{tabular}

* Evaluated during the period of stay in the North Wing Hospital Regional.

** Use of crutches six months after treatment of injuries.

joints, normal ambulation and return of the individual to normal activities 3,5 .

The main victims of this type of trauma that are hospitalized in regional hospitals are young adults. The mean age of this study was 29 years, being that part of the society that is economically active, bringing great socioeconomic impact. The main etiologies of this trauma are motorcycle accidents and road accidents. Tibia fracture occurred in 37\% of the patients participating in this study, demonstrating the severity of the lesions. Increasingly complex lower-limb trauma in large cities is likely to occur, probably due to the increase in vehicular and motorcycle traffic, due to the difficulty of adapting the cities to the high demand of public transport. This type of trauma has a high socioeconomic cost, leading to long-term withdrawal from work, as has been observed in other studies ${ }^{7}$.

Surgical treatment of loss of lower limb substance involves several techniques and, as a basic principle, one should opt, where possible, for the simplest procedures, provided that they are effective and safe, such as skin grafts. These are used in superficial lesions where there is no need for bony filling or covering. They can also be applied in patients whose clinical status does not allow for larger procedures ${ }^{5,6}$. Studies of angiosomes, a unit composed of the skin and underlying tissue supplied by the same vessel (analogous to the sensitive dermatomes), described by Taylor ${ }^{8}$ in 2003, revolutionized flap surgery. Knowledge of the vascular pedicles of subcutaneous tissue and skin, muscle and fascia areas, as well as of the stratigraphic and segmental distribution of this vascularization, paved the way for the use of each of these structures as independent units transformed into flaps ${ }^{8}$. Perforating vessels cross the deep fascia and are responsible for the vascular supply of a particular cutaneous or fasciocutaneous region. These vessels allow the creation of flaps that spare the muscles. With a Doppler, the local perforating vessels that can serve as a vascular pedicle are mapped, allowing free flaps to be manufactured ${ }^{9,10}$.

The recent advances in microsurgical techniques, associated with modern orthopedic bone repair techniques and fixation methods, have allowed the recovery of many limbs that were doomed to amputation a long time ago ${ }^{8-10}$. The fasciocutaneous flaps have their vascularization enriched by the presence of the fascia and are less morbid than the muscular ones. On the other hand, the muscular flaps have more robust vascularization, fill larger spaces and allow a greater fight against infection ${ }^{11}$. Microsurgical flaps may be alternative options, especially in lesions of the distal third of the leg, ankle or foot ${ }^{12}$.

The vascular conditions of the limb should be evaluated both pre- and postoperatively. Circulatory diseases may make apparently well-planned flaps unfeasible. In addition, postoperative immobilization, which is fundamental in most cases, is also a predisposing factor for thromboembolic complications. 
When the patient presents loss of lower limb substance without conditions to perform the reconstructive surgical procedure (graft or flap), the area of substance loss should be prepared for reconstruction. At that moment, surgical debridement alone or associated with vacuum therapy is fundamental ${ }^{3}$. Negative pressure therapy on the lower limb loss bed controls edema, reduces exudate, decreases bacterial population, stimulates the formation of granulation tissue, and increases vascularization in the wound bed ${ }^{13-17}$. It has become an important adjuvant method in the treatment of complex wounds and should integrate the surgeons' therapeutic arsenal ${ }^{3,18}$. The application of negative pressure therapy should be done in a clean wound, without devitalized tissue or after adequate debridement, being useful in the treatment of acute traumatic wounds, acting as a bridge between the emergency treatment and the definitive skin cover ${ }^{19}$. The contraindications of negative pressure therapy are untreated osteomyelitis, presence of tissue with malignancy, presence of necrosis, exposure of vessels, nerves, organs or sites of anastomoses ${ }^{16,18}$.

In the present study, grafting was the most accomplished treatment (62.1\%), corresponding to the principle of choosing the simplest procedures when possible. The percentage of complete integration of the grafts was $86.4 \%$, a proportion attributed to patients' profile, which was mostly young, with recent wounds and without circulatory problems. The skin grafts were used in the substance-loss injuries that presented good granulation tissue, but without bone, tendon or vascular-nervous pedicles exposure ${ }^{20}$. The formation of wound granulation tissue was stimulated with surgical debridements of the devitalized tissues, dressings based on alginate or zinc oxide, and with the use of vacuum therapy. Isolated surgical debridement was required in $21 \%$ of individuals of the sample and in $12.6 \%$ it was necessary to associate debridement with vacuum therapy.

Among the flaps, fasciocutaneous ones were the most used $(21.9 \%)$, being the main surgical option of flap for the lesions of the middle and lower thirds of the leg, with emphasis on the reverse sural flap and the neighborhood flaps. As for the muscular flaps, they were mostly used to cover lesions of the upper and mi- ddle third of the leg, especially the medial head gastrocnemius muscle flap. Similar data were presented by Franco et al. ${ }^{21,22}$. The medial head gastrocnemius muscle flap is a good option to cover bone exposures of the upper and middle third of the leg and does not leave motor sequelae. It was performed in 12 patients $(10.1 \%)$ of this sample. Similar results have been seen in other studies, including concomitant use of the soleus muscle or in combination with a fasciocutaneous flap. In addition, sectioning the origin of the medial head of the gastrocnemius in the medial condyle of the femur and / or the tendons of the goose leg (tendon of the sartorius, gracilis and semitendinosus muscles) is a way of increasing the arc of rotation of this muscular flap ${ }^{23,24}$.

Distal reverse pedicle flaps, such as the reverse sural, have proved to be very useful and versatile, especially for lesions of the distal third of the leg ${ }^{25,26}$. This flap was used in $12(10.1 \%)$ patients, similar to another study. Another useful flap in the reconstruction of the distal regions of the lower limb, mainly in the calcaneus and on the Achilles tendon, is the medial plantar flap.

The study pointed to a significant association between the presence of tibia fracture at the beginning of treatment and the need for crutches to ambulate after six months of limb reconstruction $(O R=13.8$; $\mathrm{p}<0.01)$. We observed the same significant association with the presence of the external fixator and with the bone exposure $(O R=11.5, p<0.01, O R=4.5, p<0.01$, respectively). Patients who presented severe trauma with bone fracture, bone exposure or need for external fixators are significantly more likely to present functional impairment of the limb after six months of coverage of the lower limb substance loss27.

This study demonstrated that the epidemiological profile of the patient admitted to a regional public hospital for treatment of loss of substance in the lower limb was a young adult, male, motorcycle accident victim. The graft was the most used treatment, followed by fasciocutaneous flaps of the reverse sural type or of the neighborhood. Among the muscular flaps, the flap of the medial head of the gastrocnemius is prominent. Orthopedic trauma with bone fracture, bone exposure or the presence of external fixator were associated with an increased risk of limb functional impairment requiring crutches for walking six months after treatment. 


\title{
R E S U M O
}

\begin{abstract}
Objetivo: avaliar o perfil epidemiológico, o tratamento cirúrgico e os resultados pós-operatórios de pacientes com feridas complexas traumáticas de membros inferiores. Método: estudo retrospectivo dos pacientes com ferimentos complexos traumáticos tratados pelo Serviço de Cirurgia Plástica de um hospital regional de Brasília. Foram analisados os dados clínico-epidemiológicos, o tipo de procedimento cirúrgico e a recuperação funcional do membro após seis meses do tratamento. Resultados: foram tratados 119 pacientes, com média de idade de 29 anos, predominantemente homens (76,4\%). O acidente moto ciclístico foi responsável pela maioria das lesões, em $37,8 \%$ dos casos. O tratamento cirúrgico mais realizado foi o enxerto de pele $(62,1 \%$ dos casos), seguido pelo retalho fasciocutâneo $(21,9 \%)$, o retalho muscular $(12,6 \%)$ e o retalho microcirúrgico $(3,4 \%)$. Seis meses após a conclusão do tratamento cirúrgico, $35,3 \%$ dos pacientes necessitavam de muletas para se locomover, caracterizando um atraso na recuperação funcional do membro que, no entanto, estava relacionado significativamente à presença de fratura, de fixador externo ou de exposição óssea no pré-operatório. Conclusão: o perfil do paciente com ferida complexa traumática de membros inferiores foi homem, vítima de acidente motociclístico e o enxerto foi o tratamento mais utilizado. O trauma ortopédico com fratura óssea, exposição óssea e a presença de fixador externo estiveram associados significativamente a um maior risco de prejuízo funcional do membro com necessidade de muletas para locomoção após seis meses de tratamento.
\end{abstract}

Descritores: Extremidade Inferior. Ferimentos e Lesões. Retalhos Cirúrgicos. Cirurgia Plástica. Perfil de Saúde.

\section{REFERENCES}

1. Ong YS, Levin LS. Lower limb salvage in trauma. Plast Reconstr Surg. 2010;125(2):582-8.

2. Pelissier P, Boireau P, Martin D, Baudet J. Bone reconstruction of the lower extremity: complications and outcomes. Plast Reconstr Surg. 2003; 11(7)1:22239.

3. Coltro PS, Ferreira MC, Batista BPS, Nakamoto HA, Milcheski DA, Tuma Júnior P. Atuação da cirurgia plástica no tratamento de feridas complexas. Rev Col Bras Cir. 2011;38(6):381-6.

4. Fairbanks GA, Murphy RX Jr, Wasser TE, Morrissey WM. Patterns and implications of lower extremity injuries in a community level I trauma center. Ann Plast Surg. 2004;53(4):373-7.

5. Whitaker IS, Rozen WM, Shokrollahi K. The management of open lower limb fractures: the journey form amputation to evidence-based reconstruction and harpsichords. Ann Plast Surg. 2011;66(1):3-5.

6. Reddy V, Stevenson TR. MOC-PS(SM) CME article: lower extremity reconstruction. Plast Reconstr Surg. 2008;121(4 Suppl):1-7.

7. MacKenzie EJ, Morris JA Jr, Jurkovich GJ, Yasui Y, Cushing BM, Burgess AR, et al. Return to work following injury: the role of economic, social, and jobrelated factors. Am J Public Health. 1998;88(11):16307.

8. Taylor $\mathrm{Gl}$. The angiosomes of the body and their supply to perforator flaps. Clin Plast Surg. 2003;30(3):331-42.

9. Attinger CE, Evans, KK, Bulan E, Blume P, Cooper
P. Angiosomes of the foot and ankle and clinical implications for limb salvage: reconstruction, incisions, and revascularization. Plast Reconstr Surg. 2006;117(7 Suppl): 261S-93S.

10. Sgarbi MWM, Gotfryd AO. Amputação ou reconstrução da extremidade esmagada: utilização do Índice da Síndrome da Extremidade Esmagada. Acta Ortop Bras. 2006; 14(5):264-7.

11. Chan JK, Harry L, Williams G, Nanchahal J. Soft-tissue reconstruction of open fractures of the lower limb: muscle versus fasciocutaneous flaps. Plast Reconstr Surg. 2012;130(2):284e-295e.

12. Godina M. Early microsurgical reconstruction of complex trauma of the extremities. Plast Reconstr Surg. 1986;78(3):285-92.

13. Argenta LC, Morykwas MJ. Vacuum-assisted closure: a new method for wound control and treatment: clinical experience. Ann Plast Surg. 1997; 38(6):56376; discussion 577

14. Argenta LC, Morykwas MJ, Marks MW, DeFranzo AJ, Molnar JA, David LR. Vacuum-assisted closure: state of clinic art. Plast Reconstr Surg. 2006;117(7 Suppl):127S425 .

15. Wada A, Ferreira MC, Tuma P Jr, Arrunátegui G. Experience with local negative pressure (vacuum method) in the treatment of complex wounds. São Paulo Med J. 2006;124(3):150-3.

16. Lima RVKS, Coltro PS, Farina JA Jr. Terapia por pressão negativa no tratamento de feridas complexas. Rev Col Bras Cir. 2017;44(1):81-93.

17. Ferreira MC, Paggiaro AO. Terapia por pressão negativa- 
vácuo. Rev Med (São Paulo). 2010;89(3/4):142-6.

18. Anghel EL, Kim PJ. Negative-pressure wound therapy: a comprehensive review of the evidence. Plast Reconstr Surg. 2016;138(3 Suppl):129S-37S.

19. Milcheski DA, Ferreira MC, Nakamoto HA, Pereira DD, Batista BN, Tuma P Jr. Uso da terapia por pressão negativa subatmosférica em feridas traumáticas agudas. Rev Col Bras Cir. 2013;40(5):392-7.

20. Macedo JLS, Rosa SC, Botelho DL, Santos CP, Queiroz MN, Gomes TGACB. Reconstrução de membros inferiores: perfil, manejo e evolução dos pacientes do Hospital Regional da Asa Norte do Distrito Federal. Rev Col Bras Cir. 2017;44(1):9-16.

21. Franco D, D'Ávila F, Arnaud M Jr, D'Ávila B, Franco T. Tratamento das áreas cruentas de perna com retalhos locais. Rev Bras Cir Plast. 2015;30(2):264-72.

22. Parrett BM, Matros E, Pribaz JJ, Orgill DP. Lower extremity trauma: trends in the management of softtissue reconstruction of open tibia-fibula fractures. Plast Reconstr Surg. 2006;117(4):1315-22.

23. D'Avila F, Franco D, D'Avila B, Arnaut M Jr. Uso de retalhos musculares locais para cobertura de exposições ósseas na perna. Rev Col Bras Cir. 2014;41(6):434-9.

24. Macedo JLS, Rosa SC, Silva AA, Rezende Filho Neto AVF, Ruguê PHS, Scartazzini C. Versatilidade do uso do retalho do músculo gastrocnêmio medial na reconstrução de lesões de partes moles de membros inferiores. Rev Bras Cir Plast. 2016;31(4):527-33.

25. Kenser $U$, Bach $A D$, Polykandriotis E, Kopp J, Horch RE. Delayed reverse sural flap for staged reconstruction of the foot and lower leg. Plast Reconstr Surg. 2005;116(7):1910-7.

26. Follmar KE, Baccarani A, Baumeister SP, Levin LS, Erdmann D. The distally based sural flap. Plast Reconstr Surg. 2007;119(6):138e-48e.

27. Yazar $\mathrm{S}$, Lin $\mathrm{CH}$, Wei FC. One-stage reconstruction of composite bone and soft-tissue defects in traumatic lower extremities. Plast Reconstr Surg. 2004;114(6):1457-66.

Received in: 30/03/2017

Accepted for publication: 20/05/2017

Conflict of interest: none.

Source of funding: none.

\section{Mailing address:}

Ricardo Barros Martins Rezende

E-mail: ricardobmr@yahoo.com.br / jlsmacedo@yahoo. com.br 